*aMIS View/Print Document Cover Sheet

This document was retrieved from the Boeing ISEARCH System.

Accession \#: D196054821

Document \#: SD-WM-ER-451

Title/Desc:

TANK 241U107 HEADSPACE GAS \& VAPOR CHARACTERIZATION RESAULTS FOR SAMPLES COLLECTED IN 2/1995 


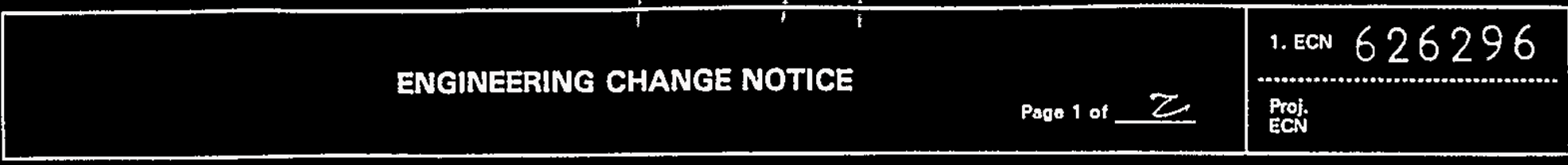

\begin{tabular}{|c|c|c|c|c|c|}
\hline \multirow{3}{*}{$\begin{array}{l}\text { 2. ECN Category } \\
\text { (mark one) } \\
\\
\text { Supplemental } \\
\text { Direct Revision } \\
\text { Change ECN } \\
\text { Temporary } \\
\text { Standby } \\
\text { Supersedure } \\
\text { Cancel/Noid }\end{array}$} & \multicolumn{2}{|c|}{$\begin{array}{l}\text { 3. Originator's Name, Organization, MsIN, } \\
\text { and Telephone No. } \\
\text { D. R. BRATZEL, 75640, S7-2I, } \\
\text { 373-3579 }\end{array}$} & \multicolumn{2}{|c|}{$\begin{array}{l}\text { 3a. USQ Required? } \\
{[] \text { Yes }[X] \text { No }}\end{array}$} & $\begin{array}{l}\text { 4. Date } \\
09 / 27 / 95\end{array}$ \\
\hline & \multicolumn{2}{|c|}{$\begin{array}{l}\text { 5. Project Title/No./Work order No. } \\
\text { TANK 241-U-107 HEADSPACE GAS } \\
\text { AND VAPOR CHARACTERIZATION } \\
\text { RESULTS FOR SAMPLES COLLECTED } \\
\text { IN FEBRUARY 1995 }\end{array}$} & \multicolumn{2}{|c|}{$\begin{array}{l}\text { 6. Bldg./Sys./Fac. No. } \\
2704 \mathrm{HV} / 200 \mathrm{E}\end{array}$} & $\begin{array}{c}\text { 7. Approval Designator } \\
\text { N/A }\end{array}$ \\
\hline & \multicolumn{2}{|c|}{$\begin{array}{l}\text { 8. Document Numbers changed by this ECN } \\
\text { (includes sheet no. and rev.) } \\
\text { WHC-SD-WM-ER-451 REV } 109 / 2)\end{array}$} & 9. Relat & CN $\mathrm{No}(\mathrm{s})$. & $\begin{array}{l}\text { 10. Related PO No. } \\
\qquad N / A\end{array}$ \\
\hline \multirow{2}{*}{$\begin{array}{l}\text { 11a. Modification Work } \\
\text { [] Yes (fill out Blk. } \\
\text { [X] No (NA Blks. 11b, } \\
11 \mathrm{c}, 11 \mathrm{~d} \text { ) }\end{array}$} & \multirow[t]{2}{*}{$\begin{array}{l}\text { 11b. Work Package } \\
\text { No. } \\
\text { N/A }\end{array}$} & \multirow{2}{*}{\multicolumn{2}{|c|}{$\begin{array}{l}\text { 11c. Modification Work Complete } \\
\text { N/A }\end{array}$}} & \multicolumn{2}{|c|}{$\begin{array}{l}\text { 11d. Restored to Original Condi- } \\
\text { tion (Temp. or Standby ECN only) } \\
\text { N/A }\end{array}$} \\
\hline & & & & Cog. In & neer signature \& Date \\
\hline
\end{tabular}

12. Description of Change

Title change and complete rewrite.

13a. Justification (mark one)

Criteria Change [X] Design Improvenent []

As-Found

Facilitate Const

[] Environmental

[]

Facility Deactivation Const. Error/Omission Design Error/Omission

13b. Justification Details

Complete rewrite which includes all vapor sampling events to date and data qualification.

14. Distribution (include name, MSIN, and no. of copies)

See attached Distribution Sheet

RELEASE STAMP

OFFIOIAL REIERSE G BY Witio

DATE SEP 2 Y IOSE

$\sum_{i} \mid c_{i} \cdot 4$ 


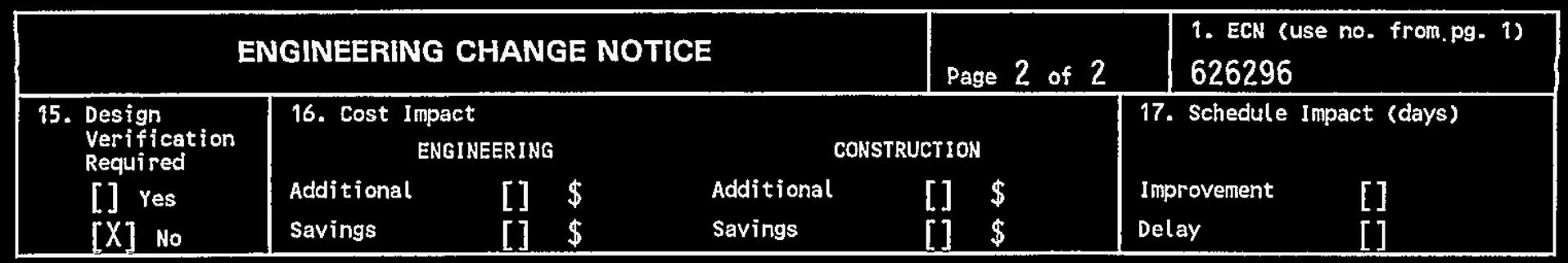

18. Change Impact Review: Indicate the related documents (other than the engineering documents identified on side 1 ) that will be affected by the change described in Block 12 . Enter the affected document number in Block 19.

SDD/DD
Functional Design Criteria
Operating Specification
Criticality Specification
Conceptual Design Report
Equipment Spec.
Const. Spec.
Procurement Spec.
Vendor Information
OM Manual
FSAR/SAR
Safety Equipment List
Radiation Work Permit
Environmental impact Statement
Environmental Report
Environmental Permit

[.] Seismic/Stress Analysis

[]

[]

[.]

[]

[]

[]

[]

[]

[]

[]

[]

[]

[]

[]
Interface Control Drawing

Calibration Procedure

Installation Procedure

Maintenance Procedure

Engineering Procedure

Operating Instruction

Operating Procedure

Operational Safety Requirement

IEFD Drawing

Cell Arrangement Drawing

Essential Material Specification

Fac. Proc. Samp, Schedule

Inspection Plan

Inventory Adjustment Request
[]

[]

[]

[]

[]

[]

[]

[]

[]

[]

[]

[]

[]

[]

[]
[]

[]

[]

[]

[]

[]

[]

[]

[]

[]

[]

[]

[]

[]

[1]

19. Other Affected Documents: (NOTE: Documents Listed below will not be revised by this ECN.) Signatures below indicate that the signing organization has been notified of other affected documents listed below. Document Number/Revision

Document Number Revision

20. Approvals

signature

OPERATIONS AND ENGINEERING
Cog. Eng. D. R. Bratzel DR

Cog. Mgr. T. J. Kelley

Safety

Environ.

other

Proj.

Proj.

Proj.

Proj.

\begin{tabular}{lll} 
Date & \multicolumn{1}{c}{ Signature } \\
\hline & $\begin{array}{l}\text { ARCHITECT-EWGINEER } \\
\text { Design } \\
\text { Environ. }\end{array}$ & \\
\hline & $\begin{array}{l}\text { Other } \\
\text { DAfety }\end{array}$ & \\
\hline & $\begin{array}{l}\text { DEPARTMENT OF ENERGY } \\
\text { Signature or a Control Number that } \\
\text { tracks the Approval signature }\end{array}$ & \\
\hline & ADDITIONAL & \\
\hline
\end{tabular}




\begin{tabular}{|c|c|}
\hline$S E^{2}{ }^{\circ}$ & RELEASE AUTHORIZATION \\
\hline Document Number: & WHC-SD-WM-ER-451, REV 1 \\
\hline Document Title: & $\begin{array}{l}\text { Tank 241-U-107 Headspace Gas and Vapor } \\
\text { Characterization Results for Samples Collected in } \\
\text { February } 1995\end{array}$ \\
\hline Release Date: & 9/26/95 \\
\hline \multicolumn{2}{|c|}{$\begin{array}{l}\text { This document was reviewed following the } \\
\text { procedures described in WHC-CM-3-4 and is: } \\
\text { APPROVED FOR PUBLIC RELEASE }\end{array}$} \\
\hline WHC Information Re & ase Administration Specialist: \\
\hline
\end{tabular}

TRADEHARK DISCLAIMER. Reference herein to any specific commercial product, process, or service by trade name, trademark, manufacturer, or otherwise, does not necessarily constitute or imply its endorsement, recommendation, or favoring by the United States Government or any agency thereof or its contractors or subcontractors.

This report has been reproduced from the best available copy. Available in paper copy. Printed in the United States of America. To obtain copies of this report, contact:

Westinghouse Hanford Company - Document Control Services

P.0. Box 1970, Mailstop H6-08, Richland, WA 99352

Telephone: (509) 372-2420; Fax: (509) 376-4989 
2. Title

TANK 241-U-107 HEADSPACE GAS AND VAPOR

CHARACTERIZATION RESULTS FOR SAMPLES COLLECTED IN FEBRUARY 1995

5. Key Words

CHARACTERIZATION OBJECTIVES, TANK HEADSPACE, SAMPLING EVENT, INORGANIC GASES, ORGANIC VAPORS
3. Number

WHC-SD-WH-ER-451
4. Rev No.

1

6. Author

Name: D. R. BRATZEL

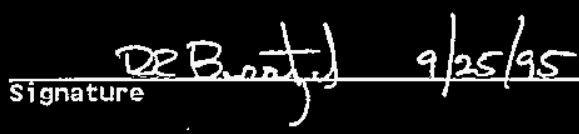

Organization/Charge Code

$75640 / \mathrm{N} 4 \mathrm{AB} 1$

\section{Abstract}

Significant changes have been made to all of the original vapor characterization reports. This report documents specific headspace gas and vapor characterization results for all vapor sampling events to date. In addition, changes have been made to the original vapor reports to qualify the data based on quality assurance issues associated with the performing laboratories.

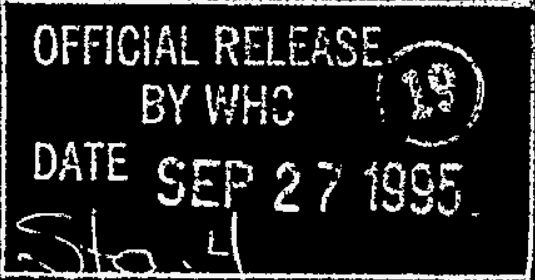




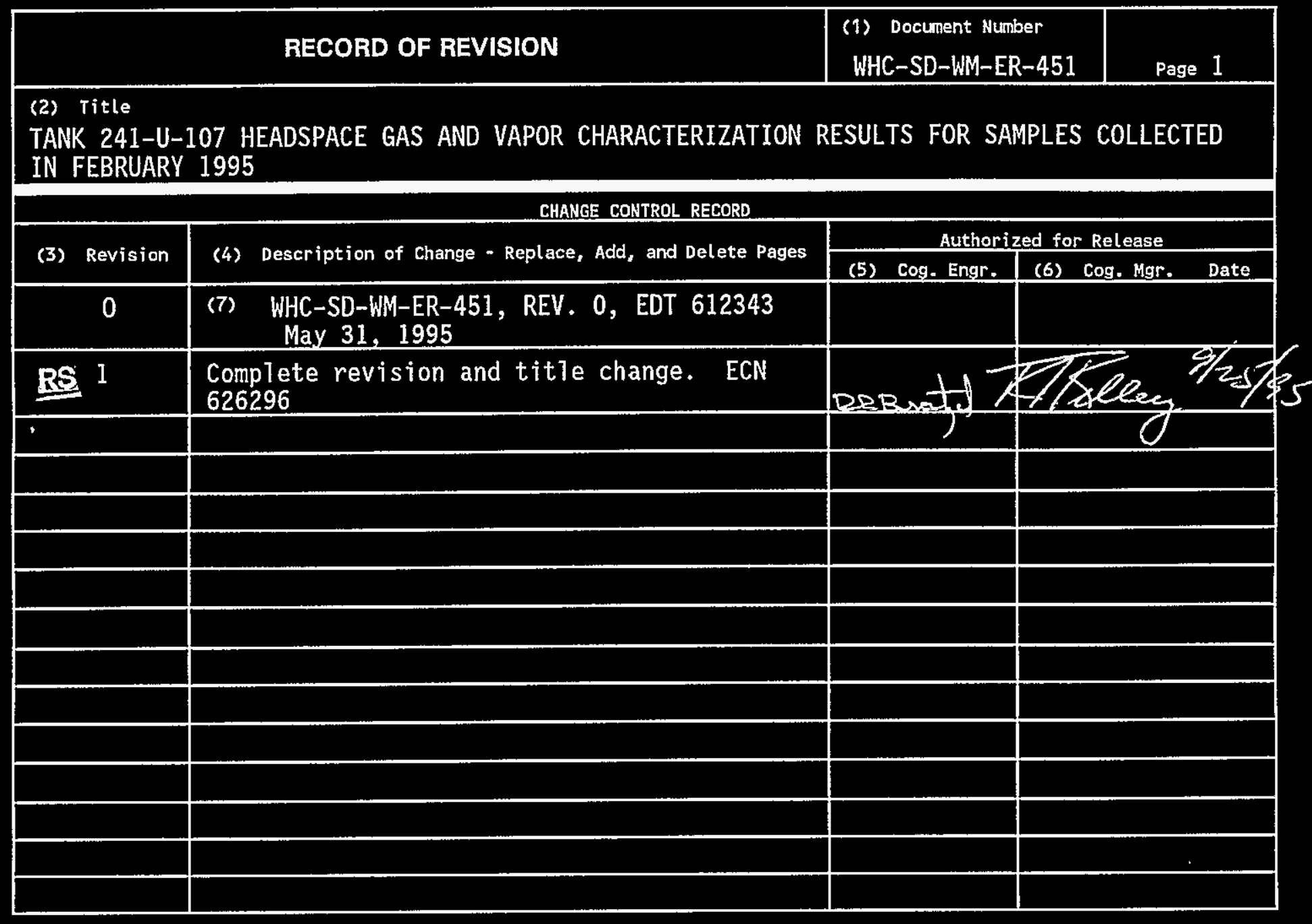




\title{
Tank 241-U-107 Headspace Gas and Vapor Characterization Results for Samples Collected in February 1995
}

\author{
J. L. Huckaby \\ Pacific Northwest Laboratories \\ D. R. Bratzel \\ Westinghouse Hanford Company
}

Date Published

September 1995

Prepared for the U.S. Department of Energy Office of Environmental Restoration and Waste Management

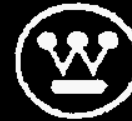




\section{Contents}

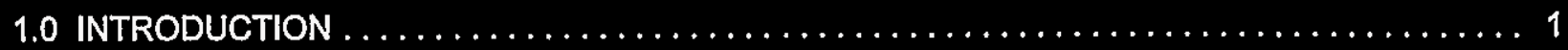

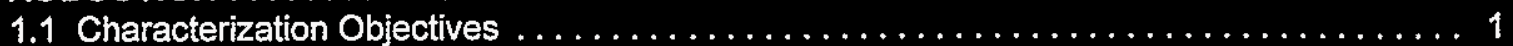

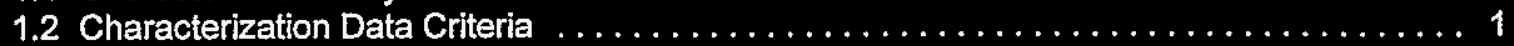

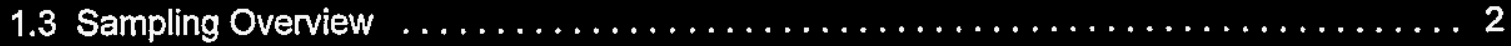

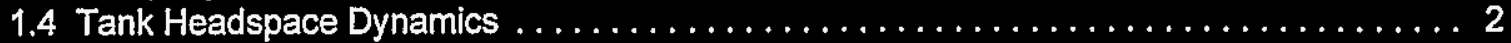

2.0 SAMPLING EVENT $\ldots \ldots \ldots \ldots \ldots \ldots \ldots \ldots \ldots \ldots \ldots \ldots \ldots \ldots \ldots \ldots \ldots \ldots \ldots \ldots \ldots \ldots$

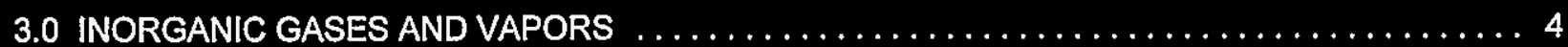

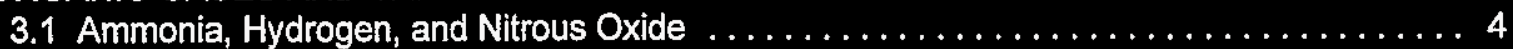

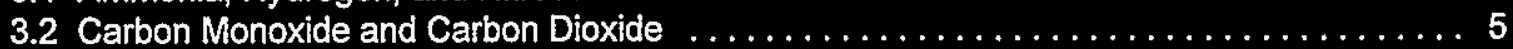

3.3 Nitric Oxide, Nitrogen Dioxide, Water and Tritium $\ldots \ldots \ldots \ldots \ldots \ldots \ldots \ldots \ldots \ldots$

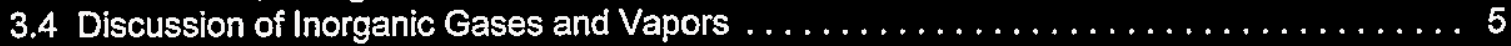

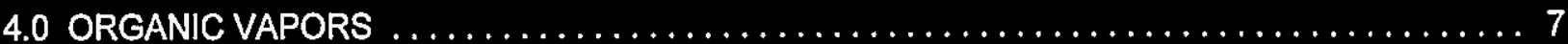

4.1 Positively Identified Organic Compounds . . . . . . . . . . . . . . . . . . 7

4.2 Tentatively Identified Organic Compounds $\ldots \ldots \ldots \ldots \ldots \ldots \ldots \ldots \ldots \ldots \ldots$

4.3 Discussion of Organic Compounds $\ldots \ldots \ldots \ldots \ldots \ldots \ldots \ldots \ldots \ldots \ldots \ldots, \ldots$

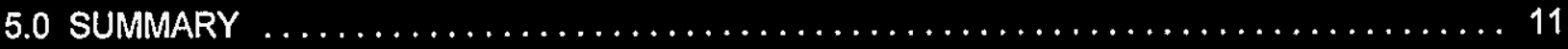

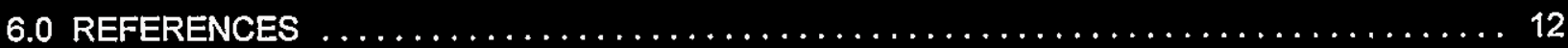

\section{Acronyms and Abbreviations}

$\begin{array}{ll}\text { CES } & \text { consensus exposure standard } \\ \text { EPA } & \text { Environmental Protection Agency } \\ \text { GC } & \text { gas chromatograph } \\ \text { GC/MS } & \text { gas chromatograph/mass spectrometer } \\ \text { LFL } & \text { lower flammability limit } \\ \text { MS } & \text { mass spectrometer } \\ \text { NFPA } & \text { National Fire Protection Association } \\ \text { NPH } & \text { normal paraffinic hydrocarbon } \\ \text { ORNL } & \text { Oak Ridge National Laboratory } \\ \text { PNL } & \text { Pacific Northwest Laboratory } \\ \text { ppmv } & \text { parts per million by volume, } 1 \text { ppmv = } 10^{-4} \text { vol\% } \\ \text { TST } & \text { triple sorbent trap } \\ \text { vol\% } & \text { percent by volume, } 1 \text { vol\% }=10,000 \text { ppmv } \\ \text { VSS } & \text { vapor sampling system } \\ \text { Wt\% } & \text { percent by weight } \\ \text { WHC } & \text { Westinghouse Hanford Company }\end{array}$

\section{Acknowledgements}

The authors wish to thank Chris Simonen for her work verifying data and generating tables, and Shas Mattigod for his help with the construction and reviews of this document. The authors also wish to thank Luther Buckley, Clarence Homi, and Tom Kunthara for their contributions to the final reviews and publication of this document. 
WHC-SD-WM-ER-451 REV. 1

Tank 241-U-107 Headspace Gas and Vapor Characterization Results

for Samples collected in February 1995

\subsection{INTRODUCTION}

\subsection{Characterization Objectives}

Tank U-107 headspace gas and vapor samples were collected and analyzed to help determine the potential risks of fugitive emissions to tank farm workers. The drivers and objectives of waste tank headspace sampling and analysis are discussed in Program Plan for the Resolution of Tank Vapor Issues (Osborne and Huckaby 1994). Tank U-107 was vapor sampled in accordance with Data Quality Objectives for Generic In-Tank Health and Safety lssue Resolution (Osborne et al. 1994).

\subsection{Characterization Data Criteria}

Data Quality Objectives for Generic In-Tank Health and Safety Issue Resolution describes parameters for data collection to ensure appropriate conclusions can be drawn from the data. Tank headspace characterization data were collected to help in the evaluation of 1) headspace flammability, and 2) identification and quantification of compounds of toxicological concern.

Single Shell Tank Interim Operational Safety Requirements (Dougherty 1995) specifies that combustible constituents in tank headspaces be maintained below $25 \%$ of the lower flammability limit (LFL). This essentially agrees with National Fire Protection Association requirements that combustible concentrations be maintained at or below $25 \%$ of the LFL (NFPA 1994). However, current governing operating specifications for Watchlist waste tanks, such as tank U-107 specify that combustible constituents be maintained at or below $20 \%$ of the LFL (WHC 1995a).

Headspace characterization data are used by Westinghouse Hanford Company (WHC) Tank Waste Remediation Systems Industrial Hygiene as source term data in the industrial hygiene strategy to protect workers from tank fugitive emissions. Because selection of worker protective equipment must be based on industrial hygiene monitoring of the work place and not on source term data (29 CFR 1910.120), tank headspace characterization data can not be used for this purpose. Furthermore, because there are mechanisms by which headspace constituents can be either diluted or concentrated as they are released to the atmosphere, the headspace characterization data should not be considered to be representative of emissions at the point of emission.

These statements notwithstanding, the data quality objectives document specifies that the industrial hygiene group be advised if constituents with toxicological properties exceed $50 \%$ of the appropriate consensus exposure standard (CES) for non-carcinogens, or $10 \%$ of the appropriate CES for carcinogens. A CES is defined as the most stringent of known regulatory or recommended toxicological values for the workplace (Osborne et al. 1994). 


\subsection{Sampling Overview}

Tank headspace characterization data presented here are from a single sampling event. Samples collected are thought to have been representative of tank U-107 headspace when the tank was sampied (Meacham et al. 1995), and samples analyses were designed to provide a reasonably accurate and complete characterization of the significant headspace constituents. No assessment has been made as to how the tank U-107 headspace composition changes with time, though studies of tank C-103 suggest that composition changes probably occur very slowly in the passively ventilated tanks (Huckaby and Story 1994)

\subsection{Tank Headspace Dynamics}

Tank U-107 is the first tank in a 3-tank cascade with tanks U-108 and U-109. It is connected to tank U108 via a 7.4-cm (2.9-in.) inside diameter, 7.6-m (25-ft) long cascade line. A similar line connects tanks U108 and U-109. Since these cascade lines connect the headspaces of these tanks, gases and vapors originating from the wastes in tank $\mathrm{U}-108$ or tank $\mathrm{U}-109$ may be transferred to tank $\mathrm{U}-107$ (unless the cascade lines are obstructed). At this time, however, no headspace characterization data are available for tank U-108 to assess their potential transfer of gases and vapors to tank U-107.

The cascade of tanks $\mathrm{U}-107, \mathrm{U}-108$, and $\mathrm{U}-109$ is passively ventilated, which means that the tanks are allowed to exhale air, waste gases, and vapors as the barometric pressure falls, and inhale ambient air as the barometric pressure rises. Each of these tanks has its own filtered breather riser. Barometric pressure typically rises and falls on a diurnal cycle, producing an average daily exchange of air equal to about $0.46 \%$ of each tank headspace (Huckaby 1994). Changes in the concentrations of tank headspace constituents due to barometric pressure changes are consequently very slow. 


\subsection{SAMPLING EVENT}

Headspace gas and vapor samples were collected from tank U-107 using the vapor sampling system (VSS) on February 17, 1995 by WHC Sampling and Mobile Laboratories (WHC 1995). Sample collection and analysis were performed as directed by Tank 241-U-107 Tank Characterization Plan (Carpenter 1995). The tank headspace temperature was determined to be $22.6^{\circ} \mathrm{C}$. Air from the $\mathrm{U}-107$ headspace was withdrawn from a single elevation via a $6.1-\mathrm{m}$ long heated sampling probe mounted in riser 10 , and transferred via heated tubing to the VSS sampling manifold. All heated zones of the VSS were maintained at approximately $60^{\circ} \mathrm{C}$. All tank air samples were collected between 12:03 p.m. and 3:45 p.m., with no anomalies noted.

Sampling media were prepared and analyzed by WHC, Oak Ridge National Laboratories (ORNL), and Pacific Northwest Laboratories (PNL). The 40 tank air samples and 2 ambient air control samples collected are listed in Table 2-1 by analytical laboratory. Table 2-1 also lists the 14 trip blanks and 2 field blanks provided by the laboratories.

A general description of vapor sampling and sample analysis methods is given by Huckaby and Babad (1995). The sampling equipment, sample collection sequence, sorbent trap sample air flow rates and flow times, chain of custody information, and a discussion of the sampling event itself are given in WHC 1995b. 


\subsection{INORGANIC GASES AND VAPORS}

Analytical results of sorbent trap and SUMMA ${ }^{T M, 1}$ canister tank air samples for selected inorganic gases and vapors are given in Table 3-1 in parts per million by volume (ppmv) in dry air. The concentration of water vapor given in Table 3-1 has been adjusted to tank conditions and are given in Section 3.3. Inorganic anaiyte sorbent traps and SUMMA ${ }^{\mathrm{TM}}$ canisters were prepared and analyzed by PNL at quality assurance impact level 2 (McVeety et al. 1995a).

Sorbent trap sample and SUMMA ${ }^{\mathrm{TM}}$ canister sample inorganic compound analyses were performed within 21 and 44 days, respectively, of sample collection (Ligotke 1995). These satisfied the administratively chosen 60-day holding time requirement of the WHC quality assurance project plan (Keller 1994). It should be noted that these inorganic compounds (i.e., the permanent gases) would be expected to be very stable in the SUMMA ${ }^{T M}$ canisters, and the results may not have been affected even if the 60 day holding time requirements had been exceeded. No holding time study has been performed to address the stability of these inorganic compounds in SUMMA ${ }^{\text {TM }}$ canisters in the chemical matrix of the waste tank samples.

\subsection{Ammonia, Hydrogen, and Nitrous Oxide}

The concentration of ammonia in the headspace of tank U-107 was 453 ppmv. Ammonia has been observed in virtually all of the passively ventilated waste tanks sampled to date, at concentrations ranging from about 3 ppmv in tank C-108 (Lucke et al. 1995), to 1040 ppmv in BY-108 (McVeety et al. 1995b). Given the lower flammability limit (LFL) of ammonia in air is about $15 \%$ by volume (vol\%), the measured 453 ppmv corresponds to about $0.3 \%$ of the $\mathrm{LFL}$, and does not contribute appreciably to the flammability of the headspace.

The concentration of hydrogen in tank U-107 was determined to be 500 ppmv. Hydrogen in the waste tanks is of concern as a fuel. Given that the lower flammability limit (LFL) for hydrogen in air is about $4 \%$ by volume, $500 \mathrm{ppmv}$ hydrogen concentration in tank U-107 corresponds to about $1.3 \%$ of its LFL. At this level, hydrogen is not a flammability concern in tank U-107.

The nitrous oxide concentration in tank $U-107,701$ ppmv, is the second highest measured in any waste tank to date. Nitrous oxide has been detected in other passively ventilated waste tanks at average concentrations as low as about 12 ppmv in tank TX-105 (Klinger 1995), and as high as 878 ppmv in tank U-103 (Ligotke et al. 1995). Under proper conditions, nitrous oxide can serve as an oxidizer to support combustion. However, Cashdollar et al. (1992) found that nitrous oxide had no significant effect on the flammability of hydrogen and air mixtures for hydrogen concentrations less than 20 vol\%, and that "small amounts of nitrous oxide (relative to air) do not appear to have much effect on the flammability". Their results suggest the measured nitrous oxide concentration is much too low to have a significant effect on the flammability of the tank U-107 headspace.

1 SUMMA is a trademark of Molectrics, Inc., Cleveland, Ohio. 


\subsection{Carbon Monoxide and Carbon Dioxide}

Carbon monoxide in the tank U-107 headspace was reported as $<12$ ppmv In ambient air it typically ranges from 0.05 to $0.15 \mathrm{ppmv}$. Because different analytical methods have been used to measure carbon monoxide in the waste tanks sampled to date, the information on carbon monoxide has varied from tank to tank. However, elevated waste tank headspace carbon monoxide concentrations are common, and are thought to be due to the decomposition of organic waste in the tanks. Carbon monoxide has not been measured at very high levels in any of the waste tanks, the highest level measured to date was [26.7 ppmv] in tank C-1032 (Huckaby and Story 1994).

The carbon dioxide concentration in the tank U-107 headspace, measured to be $<64$ ppmv, is significantly lower than it is in ambient air. Carbon dioxide introduced by air exchange with the atmosphere is readily absorbed by caustic supernatant and interstitial liquids of the waste tanks, and converted to carbonate in solution. Carbon dioxide is normally present in the ambient air at a concentration of 350 to 400 ppmv, and is typically lower than ambient in the waste tank headspaces. The carbon dioxide in tank U-107, at $<64$ ppmv, is typical of its value in other passively ventilated tanks that have been sampled.

\subsection{Nitric Oxide, Nitrogen Dioxide, Water and Tritium}

Nitric oxide and nitrogen dioxide concentrations in the tank U-107 headspace were determined to be $s$ 0.06 and $\leq 0.03 \mathrm{ppmv}$, respectively. These are acid gases that would have very low equilibrium concentrations above the high pH sludge in tank $\mathrm{U}-107$. The measurable presence of nitric oxide is not uncommon in the waste tank headspaces, and may be due to its formation from oxygen and nitrogen in the radiation field of the headspace. These constituents could potentially serve as oxidizers to support combustion, but at the measured concentrations would have a negligible effect on the flammability of the tank U-107 headspace.

The water vapor concentration of tank U-107 was determined to be about $11.4 \mathrm{mg} / \mathrm{L}$, at the measured tank headspace temperature of $22.6^{\circ} \mathrm{C}$ and pressure of $982.8 \mathrm{mbar}(737.3 \mathrm{torr})$, (WHC 1995b). This corresponds to a water vapor partial pressure of $15.5 \mathrm{mbar}\left(11.6\right.$ torr), to a dew point of $13.5^{\circ} \mathrm{C}$, and to a relative humidity of $57 \%$.

Silica gel sorbent traps were used to test for tritium. It is assumed that tritium produced by the waste combines with hydroxide ions to form tritium-substituted water. Evaporation of the tritium-substituted water would then result in airborne radioactive contamination. Silica gel sorbent traps adsorb virtually all (normal and tritium-substituted) water vapor from the sampled tank air, and are analyzed at the WHC 222S laboratory. Radiochemical analysis of the silica gel trap indicated the total activity of the headspace to be less than $50 \mathrm{pCi} / \mathrm{L}$ (WHC 1995b).

\subsection{Discussion of Inorganic Gases and Vapors}

Aside from water vapor, the most abundant waste constituents in the tank $\mathrm{U}-107$ headspace are nitrous oxide, hydrogen, and ammonia. These gases have been detected in most tank headspaces sampled to

\footnotetext{
${ }^{2}$ The carbon monoxide measurement in tank C-103 was made by Oregon Graduate Institute of Science and Technology, and have been placed in brackets to indicate it should be considered secondary data.
} 


\section{WHC-SD-WM-ER-451 REV. 1}

date, and are usually the dominant species. The concentrations of these 3 compounds are higher in tank $\mathrm{U}-107$ than in most other passively ventilated tanks that have been sampled.

The relative standard deviations of the inorganic gas and vapor results given in the last column in Table 31 are excellent for the methods used. Relative standard deviations range from less than $1 \%$ for nitrous oxide and hydrogen to $4.4 \%$ for ammonia. Because the precision reported depends both on sampling parameters (e.g., sample flow rate and flow time for sorbent traps) and analytical parameters (e.g., sample preparation, dilutions, etc.), small relative standard deviations suggest proper control was maintained both in the field and in the laboratories. 


\subsection{ORGANIC VAPORS}

Organic vapors in the tank U-107 headspace were sampled using SUMMATM canisters, which were analyzed by PNL, and triple sorbent traps (TSTs), which were analyzed by ORNL. Both PNL and ORNL used a gas chromatograph (GC) equipped with a mass spectrometer (MS) detector to separate, identify, and quantitate the analytes. Descriptions of sample device cleaning, sample preparations, and analyses are given by Jenkins et al. (1995a) and MoVeety et al. (1995a).

SUMMATM sample results should be considered to be the primary organic vapor data for tank U-107. These results were produced at PNL quality assurance impact level 2. All PNL analyses were completed 46 days after sample collection, and within the administratively chosen 60-day holding time (Keller 1994). However, no holding time study has been performed to determine the stability of organic analytes in SUMMA ${ }^{\text {TM }}$ canisters in the typical chemical matrix of the tank headspace samples.

ORNL analyses of TST samples from this and other waste tanks generally agree with, support, and augment the SUMMA ${ }^{\mathrm{TM}}$ sample results. However, because certain WHC quality assurance requirements were not satisfied by ORNL, the quality assurance assessment of ORNL by Hendrickson (1995) should be reviewed before results unique to the TST samples are used for decision making.

All TSTs prepared by ORNL had 3 surrogate compounds added to evaluate sample matrix effects, potential handling, storage, and shipment problems, and analytical instrumentation performance (Jenkins et al. 1995a). ORNL evaluated the surrogate recoveries using a statistical approach similar to that prescribed by SW 846 Method 8260A Volatile Organic Compounds by Gas Chromatography/Mass Spectrometry (GC/MS) Capillary Column Technique (EPA 1992). Using this approach, ORNL reported that all surrogates had standard deviation values within the $95 \%$ confidence interval for variance, indicating that no bias was introduced in the measurement of analyte quantities (Jenkins 1995a).

\subsection{Positively Identified Organic Compounds}

Positive identification of organic analytes using the methods employed by PNL and ORNL involves matching the GC retention times and MS data from a sample with that obtained from the analysis of standards. The concentration of an analyte in the sample is said to be quantitatively measured if the response of the GC/MS has been established at several known concentrations of that analyte (i.e., the GCMS has been calibrated for that analyte), and the MS response to the analyte in the sample is between the lowest and highest responses to the known concentrations (i.e., the analyte is within the calibration range).

ORNL and PNL were assigned different lists of organic compounds, or target analytes, to positively identify and measure quantitatively. The ORNL target analyte list was derived from a review of the tank C103 headspace constituents by a panel of toxicology experts (Mahlum et al. 1994). The PNL target analyte list included 39 compounds from the Environmental Protection Agency (EPA) task order 14 (TO14) method, which are primarily halocarbons and common industrial solvents (EPA 1988), plus 14 analytes selected mainly from the toxicology panel's review of tank $\mathrm{C}-103$.

Both PNL and ORNL report target analyte concentrations in ppmv of analyte in dry air. To correct for the measured water vapor content of tank U-107 and obtain concentration in ppmv of analyte in moist tank air, multiply by 0.984 . 


\section{WHC-SD-WM-ER-451 REV. 1}

Table 4-1 lists the organic compounds positively identified and quantitated in SUMMA ${ }^{\mathrm{TM}}$ samples. SUMMA ${ }^{\mathrm{TM}}$ analyses were performed according to the TO-14 methodology, except for analysis of methane, which was analyzed with the inorganic gases (MoVeety et al. 1995a). Only 6 of the 39 TO-14 target analytes and 6 of the 14 additional target analytes were measured to be above the 0.005 ppmv detection limit of the analyses. Averages reported are from analyses of 3 SUMMA ${ }^{\mathrm{TM}}$ canister samples.

Jenkins et al. (1995a) report the positive identification of 20 of 27 target analytes in TST samples. 1,1Dichloroethene, butanal, 2-pentanone, $n$-hexanenitrile, $n$-heptanenitrile, dibutyl butylphosphonate, and tributyl phosphate were the only TST target analytes not detected. Despite calibration of the instrument over about a 20-fold concentration range, 14 of the positively identified compounds were outside of the calibration range in at least 1 of the TST samples. The average concentrations of the organic compounds positively identified by ORNL in 3 TST samples are given in Tables 4-2, 4-3, and 4-4. Table 4-2 lists the 5 quantitated analytes, Table 4-3 lists the positively identified analytes for which at least 1 sample result was outside the instrument calibration range (i.e., not quantitated), and Table $4-4$ lists the single analyte determined to have exceeded its ORNL practical holding time. Tables 4-2, 4-3, and 4-4 are mutually exclusive, so that no analyte appears in more than 1 of these tables.

The ORNL practical holding time is defined as the holding time for which there is a $15 \%$ risk that the concentration of an anaiyte in the sample will be below its initial concentration (Jenkins et al. 1995b). As indicated in Table 4-4, 1-butanol was the only analyte that exceeded its practical holding time. Jenkins (1995b) report the practical holding times of butanal, 1-butanol, and 2-pentanone (1, 17, and 34 days, respectively) were exceeded by the 49 day period between sample collection and analysis. It is possible that butanal and 2-pentanone were not identified in the tank U-107 TST samples because the practical holding times for these compounds were exceeded. It should be noted that the contractual holding time for the TST samples was 60 days.

Eleven target analytes were common to both TST and SUMMA ${ }^{\mathrm{TM}}$ analyses. Table 4-5 lists these, and their reported average concentrations in TST and SUMMA ${ }^{\mathrm{TM}}$ samples. Results from these 2 sampling and anaiytical methods are in fairly good agreement for toluene. As indicated in Table 4-5, the reported concentrations of 1,1-dichloroethene, dichloromethane, n-butanenitrile, n-hexane, n-heptane, and ndecane in TST samples were near or below the SUMMA ${ }^{\text {TM }}$ sample analytical detection limit, and in fair agreement with the SUMMATM sample result of $<0.005$.

The largest discrepancy between the target analyte results from the 2 methods is for ethanenitrile, which was determined to be present at $0.12 \mathrm{ppmv}$ in TST samples, and $<0.005 \mathrm{ppmv}$ in SUMMA $^{\text {TM }}$ samples. Propanone, propanenitrile, and benzene measurements in the 2 sample types also disagree. None of these compounds, however, even assuming the higher concentrations to be correct, are at or above levels of concern.

The most abundant analytes in Tables 4-1 and 4-2 are trichlorofluoromethane, propanone, and ethanenitrile, each of which was measured to be above $0.1 \mathrm{ppmv}$. At the reported concentrations, the target analytes do not individually or collectively represent a flammability hazard.

\subsection{Tentatively Identified Organic Compounds}

In addition to the target analytes, the ORNL and PNL analytical procedures allow the tentative identification of other organic compounds. Tentative identification of analytes was performed by comparing the MS molecular fragmentation patterns with a library of known MS fragmentation patterns. This method allows an organic analyte to be identified (with reasonable certainty) as an alkane, a ketone, 


\section{WHC-SD-WM-ER-451 REV. 1}

an aldehyde, etc., and may also determine its molecular weight. The method usually does not, however, allow the unambiguous identification of structural isomers, and this ambiguity increases with analyte molecular weight. Using this method, many analytes can be tentatively identified with reasonable confidence without having to inject standards of each into the GC/MS to determine their GC retention times or specific MS patterns.

By the nature of the sampling devices, virtually all organic vapors present in the tank headspace are collected by both TST and SUMMA ${ }^{T M}$ samples. Analyses of the samples are designed to recover, separate, identify, and quantify the organic vapors in the samples. TSTs are not good for collecting highly volatile compounds (i.e., molecules more volatile than propane), but are quite good for most others. In contrast, the recovery of very low volatility compounds (e.g., molecules with more than about 15 carbon atoms) and some polar compounds with moderate volatility (e.g., butanal) from SUMMA ${ }^{\text {TM }}$ samples has been problematic.

The list of tentatively identified compounds recovered from SUMMA ${ }^{\mathrm{TM}}$ samples, with estimated concentrations, is given in Table 4-6. Compounds are listed in Table 4-6 in the order by which they eluted chromatographically, and oniy non-zero results are included in the reported averages. The list of tentatively identified compounds detected in TST samples, and their estimated concentrations, is given in Table 4-7. Compounds are listed in Table 4-7 according to the order by which the eluted chromatographically. The averages reported by ORNL in Table 4-7 are all 3-sample averages, and if an analyte was not detected in a sample, its concentration in that sample was considered to be zero for averaging purposes. Estimated concentrations are in $\mathrm{mg} / \mathrm{m}^{3}$, based on dry air at $0{ }^{\circ} \mathrm{C}$ and 1.01 bar.

Because the list of tentatively identified organic compounds in TST samples is rather long and finding any given compound may be difficult, the list has been sorted both alphanumerically by compound name, as given in Table 4-8, and also in order of decreasing estimated concentrations, as given Table 4-9. Numbers in the first columns of Tables 4-8 and 4-9 (Cmpd \#) identify the location of the compound in Table 4-7.

The ORNL and PNL methods used to tentatively identify and estimate concentrations are described by Jenkins et al. (1995a) and McVeety et al. (1995a), respectively, and should be reviewed before this data are used for decision making. Concentrations given in Tables 4-6 through 4-9 should be considered rough estimates. Resuits in Tables 4-7 through 4-9 are presented in terms of observed chromatographic peaks, and are not adjusted for the occurrence of split peaks or the assignment of the same identity to different peaks (e.g., Cmpd \# 21 and 22 in Table 4-7). In these instances, the estimated concentration of a compound appearing in more than 1 peak is simpiy the sum of the individual peak estimates.

\subsection{Discussion of Organic Compounds}

A convenient way to consider the organic compounds listed in Tables 4-1 through 4-7 is to separate them into 2 categories: 1) Organic compounds added to tank U-107 as waste that are still evaporating; and 2) organic compounds that have been generated by reactions of the original waste.

Organic vapors in the first category (those that were placed into the tank as waste) include the low concentrations of semivolatile straight-chain alkanes, which were used as diluents of tributyl phosphate in various plutonium extraction processes. These alkanes (i.e., $n$-undecane, $n$-dodecane, $n$-tridecane, $n$ tetradecane, and n-pentadecane) are often referred to in Hanford site literature as the normal paraffinic hydrocarbons (NPHs). Though NPHs are positively identified in tank U-107, their concentrations are very low compared to other NPH-rich tanks. 
The tentatively identified cyclosiloxane (i.e., Cmpd \# 24 in Table 4-7) is also in this category. Small quantities of siloxanes may have been introduced to the waste tank through their use as process defoaming agents, but they may also be present in the headspace due to their use in liquid traps at the tank's breather riser.

The second category includes all organic compounds that have been generated via radiolytic and chemical reactions of the waste. The majority of compounds listed in Tables 4-1 through 4-9 fall into this category, including the alcohols, aldehydes, ketones, nitriles, alkenes, and volatile alkanes, all of which have been associated with the degradation of the NPHs.

The absence of tributyl phosphate in the tank U-107 samples does not necessarily indicate it is not present in the waste. The identification of the tributyl phosphate diluents and their degradation products is reason to expect tributyl phosphate may be present in the tank waste. 1-Butanol, which is one of the more abundant compounds in tank U-107 samples, is known to be a product of the hydrolysis of tributyl phosphate. Furthermore, informal tests by ORNL indicate that tributyl phosphate is adsorbed by the glass fiber filters used during sampling to protect the samples from radiolytic particulate contamination. Based on these considerations, the lack of tributyl phosphate in the tank U-107 headspace samples should not be taken as proof it is not present in the headspace or the waste.

On the basis of concentrations, alcohols are the dominate type of organic compound in the tank U-107 headspace. Methanol, ethanol, 1-propanol, 2-propanol, and 1-butanol account for about $63 \%$ by weight $(w t \%)$ of the total estimated concentration of organic compounds in SUMMA ${ }^{\mathrm{TM}}$ samples. Similarly, about $64 \mathrm{wt} \%$ of the total estimated organic compound concentration in TST samples is due to the same 5 aicohols. The relative abundance of alcohols is common to all the 241-U farm tanks that have been sampled. Also similar to other 241-U farm tanks, and in contrast to tanks having higher NPH concentrations, tank $\mathrm{U}-107$ has relatively few aldehydes and ketones.

The total organic vapor concentration of tank U-107 was estimated by Jenkins et al. (1995a) to be about $6.4 \mathrm{mg} / \mathrm{m}^{3}$ from the analysis of $3 \mathrm{TST}$ samples by $\mathrm{GC} / \mathrm{MS}$. A similar summation of organic compounds measured in SUMMA ${ }^{\mathrm{TM}}$ samples from tank U-107 provides an estimated total organic vapor concentration of $17.1 \mathrm{mg} / \mathrm{m}^{3}$. This disagreement is largely due to the different estimated concentrations of the dominant alcohols in the 2 sample types.

The organic vapor concentrations in tank U-107 are about average for other passively ventilated tanks that have been sampled. The organic vapors in tank U-107 clearly indicate the presence of the semivolatile NPHs and their degradation products in the tank waste. The concentrations of short-chain alcohols are higher in tank U-107 than in waste tanks with higher NPH vapor concentrations. Conversely, ketones and aldehydes are less abundant in tank U-107 than in NPH-rich waste tanks. Though tributy! phosphate was not detected in any of the headspace samples, there is strong evidence that it is also present in the waste. 


\section{WHC-SD-WM-ER-451 REV. 1}

\subsection{SUMMARY}

The tank U-107 headspace was sampled in February 1995 for gases and vapors to address flammability and industrial hygiene concerns. Collection and analysis of samples has been reported. It was determined that no headspace constituents exceeded the flammability or indrustrial hygiene notification limits specified in the current Vapor Sampling and Analysis Plan (Homi 1995b) 


\subsection{REFERENCES}

29 CFR 1910.120, 1993, "Hazardous Waste Operations and Emergency Response", Code of Federal Regulations.

Burnum, S. T., 1995, Qualification of Reported WHC Vapor Program Data, (letter 95-CHD-065 to president, Westinghouse Hanford Company, August 18), Department of Energy, Richland Operations Office, Richland, Washington.

Carpenter, B. C., 1995, Tank 241-U-107 Tank Characterization Plan, WHC-SD-WM-TP-244 Rev. OA, Westinghouse Hanford Company, Richland, Washington.

Cashdollar, K. L..,M. Hertzberg, I. A. Zlochower, C. E. Lucci, G. M. Green, and R. A. Thomas, 1992, Laboratory Flammability Studies of Mixtures of Hydrogen, Nitrous Oxide, and Air, WHC-SD-WMES-219 Rev. 0, Westinghouse Hanford Company, Richland, Washington.

Dougherty, L. F., 1995, Single Shell Tank Interim Operational Safety Requirements, WHC-SD-WM-OSR005 Rev. 0, Westinghouse Hanford Company, Richland, Washington.

EPA 1988, Compendium of Methods for the Determination of Toxic Organic Compounds in Ambient Air, PB90-127374, U.S. Environmental Protection Agency, Washington, D.C.

EPA 1992, Test Methods for Evaluating Solid Waste, SW-846 Rev. 1, U.S. Environmental Protection Agency, Washington, D.C.

Hendrickson, R. W., 1995, Tank Vapor Characterization Oak Ridge National Laboratories Quality Assurance Assessment, TWRSQA-95-0012, Westinghouse Hanford Company, Richland, Washington.

Homi, C. S., 1995b, Vapor Sampling and Analysis Plan, WHC-SD-WM-TP-335 Rev. 0G, Westinghouse Hanford Company, Richland, Washington.

Huckaby, J. L., 1994, Tank 241-C-103 Headspace Flammability, WHC-EP-0734 Rev. 1, Westinghouse Hanford Company, Richland, Washington.

Huckaby, J. L., H. Babad, and D. R. Bratzel, 1995, Headspace Gas and Vapor Characterization Summary for the 43 Vapor Program Suspect Tanks, WHC-SD-WM-ER-514 Rev. 0, Westinghouse Hanford Company, Richland, Washington.

Huckaby, J. L., 1995, Tank 241-U-103 Headspace Gas and Vapor Characterization Results for Samples Collected in February 1995, WHC-SD-WM-ER-510 Rev.0, Westinghouse Hanford Company, Richland, Washington.

Huckaby, J. L., and M. S. Story, 1994, Vapor Characterization of Tank 241-C-103, WHC-EP-0780 Rev. 0, Westinghouse Hanford Company, Richland, Washington.

Jenkins, R. A., 1995a, Untitled, (Letter 090195A to D. Bratzel, September 1), Oak Ridge National Laboratory, Oak Ridge, Tennessee. 


\section{WHC-SD-WM-ER-451 REV. 1}

Jenkins, R. A., 1995b, Untitled, (Letter 091495A to D. Bratzel, September 14), Oak Ridge National Laboratory, Oak Ridge, Tennessee.

Jenkins, R. A, A. B. Dindal, C. Y. Ma, M. A. Palausky, J. T. Skeen, and C. K. Bayne, 1995a, Analysis of Tank 241-U-107 Headspace Components, ORNL-CASD-FR-241U107.95 Rev. 0, Oak Ridge National Laboratory, Oak Ridge, Tennessee.

Jenkins, R. A, A. B. Dindal, C. Y. Ma, M. A. Palausky, J. T. Skeen, and C. K. Bayne, 1995b, Analysis of Tank 241-TY-104 Headspace Components, ORNL-CASD-FR-241TY104.95 Rev. 1, Oak Ridge National Laboratory, Oak Ridge, Tennessee.

Keller, K.K., 1994, Quality Assurance Project Plan for Tank Vapor Characterization, WHC-SD-WM-QAPP. 013 Rev.2, Westinghouse Hanford Company, Richland, Washington.

Klinger, G. S., T. W. Clauss, M. W. Ligotke, K. H. Pool, R. B. Lucke, B. D. MoVeety, O. P. Bredt, J. S. Young, M. McCulloch, J. S. Fruchter, and S. C. Goheen, 1995, Vapor Space Characterization of Waste Tank 241-TX-105: Results from Samples Collected Through the Vapor Sampling System on 12/20/94, PNL-10594 UC-606, Pacific Northwest Laboratory, Richland, Washington.

Ligotke, M. W. 1995, PNL Vapor Project Analytical Holding Times, (Letter to D.R. Bratzel, September 23, 1995), Pacific Northwest Laboratory, Richland, Washington.

Ligotke, M. W., K. H. Pool, T. W. Clauss, B. D. MoVeety, G. S. Klinger, K. B. Olsen, O. P. Bredt, J. S. Fruchter, and S. C. Goheen, 1995, Vapor Space Characterization of Waste Tank 241-U-103: Results from Samples Collected on 2/15/95, PNL-10813 UC-606, Pacific Northwest Laboratory, Richland, Washington.

Lucke, R. B., M. W. Ligotke, K. H. Pool, T. W. Clauss, A. K. Sharma, B. D. MoVeety, M. McCulloch, J. S. Fruchter, and S. C. Goheen, 1995, Vapor Space Characterization of Waste Tank 241-C-108: Results from Samples Collected Through the Vapor Sampling System on 8/5/94, PNL-10351 UC606, Pacific Northwest Laboratory, Richland, Washington.

Mahlum, D. D., J. Y. Young, and R. E. Weller, 1994, Toxicologic Evaluation of Analytes from Tank 231-C103, PNL-10189, Pacific Northwest Laboratory, Richland, Washington.

McVeety, B. D., T. W. Clauss, M. W. Ligotke, K. H. Pool, R. B. Lucke, G. S. Klinger, K. B. Olsen, O. P. Bredt, J. S. Fruchter, and S. C. Goheen, 1995a, Vapor Space Characterization of Waste Tank 241-U-107: Results from Samples Collected on 2/17/95, PNL-10729 UC-606, Pacific Northwest Laboratory, Richland, Washington.

McVeety, B. D., T. W. Clauss, M. W. Ligotke, K. H. Pool, R. B. Lucke, G. S. Klinger, J. S. Young, M. McCulloch, J. S. Fruchter, and S. C. Goheen, 1995b, Vapor Space Characterization of Waste Tank 241-BY-108: Results from Samples Collected on 10/27/94, PNL-10495 UC-606, Pacific Northwest Laboratory, Richland, Washington.

Meacham, J. E., H. Babad, R. J. Cash, G. T. Dukelow, S. J. Eberlein, D. W. Hamilton, G. D. Johnson, J. W. Osborne, M. A. Payne, D. J. Sherwood, D. A. Turner, and J. L. Huckaby, 1995, Approach for Tank Safety Characterization of Hanford Site Waste, WHC-EP-0843 Rev. 0, UC-2070, Westinghouse Hanford Company, Richland, Washington. 


\section{WHC-SD-WM-ER-451 REV. 1}

NFPA 1992, Standard on Explosion Prevention Systems, NFPA 69, National Fire Protection Association, Quincy, Massachusetts.

Osborne, J. W., and J. L. Huckaby, 1994, Program Plan for the Resolution of Tank Vapor Issues, WHCEP-0562 Rev. 1, Westinghouse Hanford Company, Richland, Washington.

Osborne, J. W., J. L. Huckaby, T. P. Rudolph, E. R. Hewitt, D. D. Mahlum, J. Y. Young, and C. M. Anderson, 1994, Data Quality Objectives for Generic In-Tank Health and Safety Issue Resolution, WHC-SD-WM-DQO-002, Westinghouse Hanford Company, Richland, Washington.

WHC 1995a, Operating Specifications for Watchlist Tanks, OSD-T-151-00030, Rev. B-9, Westinghouse Hanford Company, Richland, Washington.

WHC 1995b, Vapor and Gas Sampling of Single-Shell Tank 241-U-107 Using the Vapor Sampling System, WHC-SD-WM-RPT-152, Westinghouse Hanford Company, Richland, Washington. 


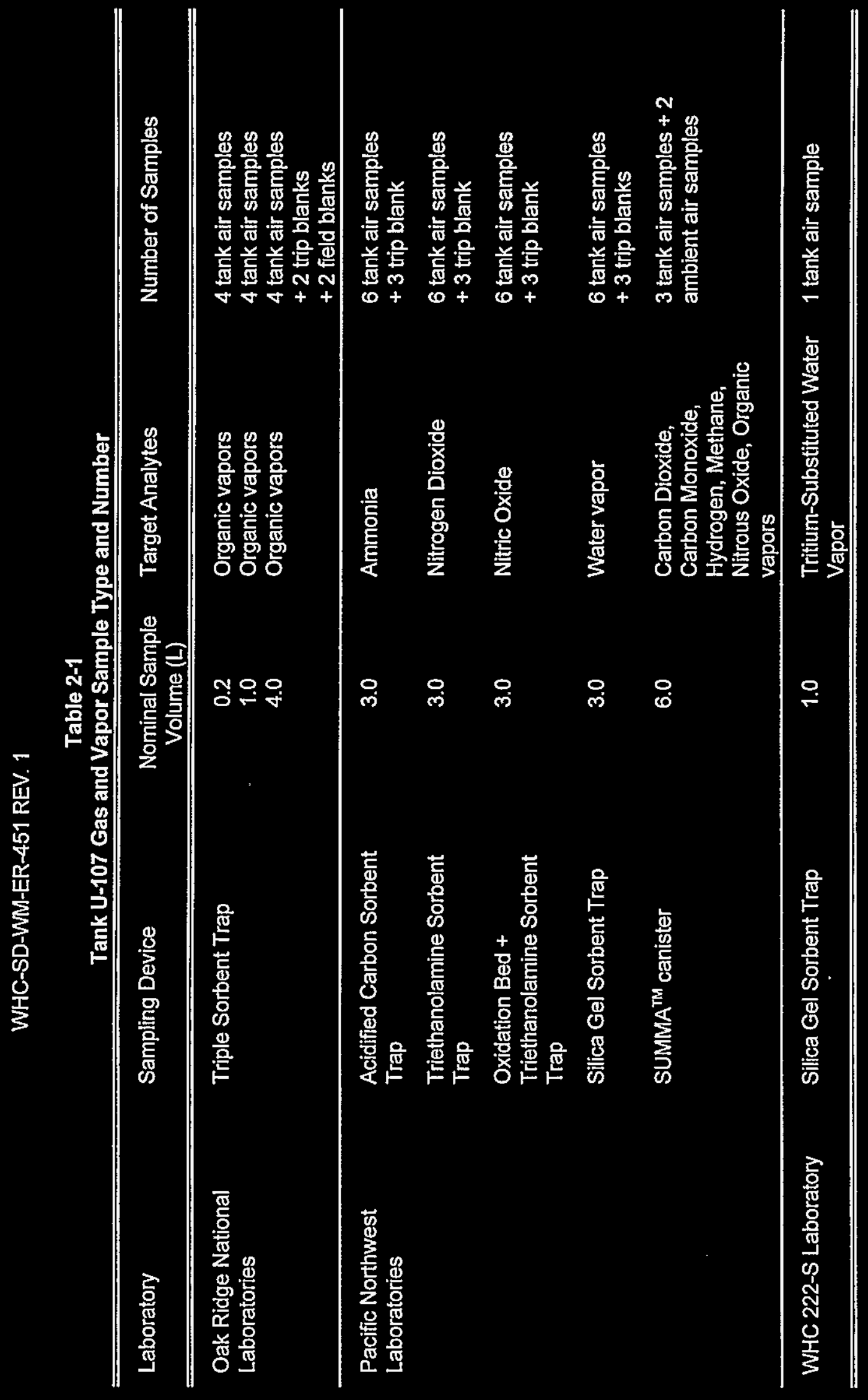

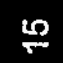


WHC-SD-WM-ER-451 REV. 1

Table 3-1

Tank U-107 Inorganic Gas and Vapor Concentrations Analyses by Pacific Northwest Laboratory

\begin{tabular}{|c|c|c|c|c|c|c|}
\hline Compound & $\mathrm{CAS}^{1}$ number & $\begin{array}{l}\text { Sample } \\
\text { Type }\end{array}$ & $\begin{array}{l}\text { Number of } \\
\text { samples }\end{array}$ & $\begin{array}{c}\text { Average } \\
\text { (ppmv) }\end{array}$ & $\begin{array}{c}\text { Standard } \\
\text { Deviation } \\
\text { (ppmv) } \\
\end{array}$ & $\begin{array}{c}\mathrm{RSD}^{2} \\
(\%)\end{array}$ \\
\hline Ammonia, $\mathrm{NH}_{3}$ & $7664-41-7$ & Sorbent Trap & 6 & 453 & 20 & 4.4 \\
\hline Carbon Dioxide, $\mathrm{CO}_{2}$ & $124-38-9$ & SUMMA ${ }^{\text {TM }}$ & 3 & $<64$ & - & - \\
\hline Carbon Monoxide, CO & $630-08-0$ & SUMMA $^{\mathrm{TM}}$ & 3 & $<12$ & - & - \\
\hline Hydrogen, $\mathrm{H}_{2}$ & $1333-74-0$ & SUMMA ${ }^{\mathrm{TM}}$ & 3 & 500 & 4.6 & 0.9 \\
\hline Nitric Oxide, NO & $10102-43-9$ & Sorbent Trap & 6 & $\leq 0.06$ & - & - \\
\hline Nitrogen Dioxide, $\mathrm{NO}_{2}$ & $10102-44-0$ & Sorbent Trap & 6 & $\leq 0.03$ & - & - \\
\hline Nitrous Oxide, $\mathrm{N}_{2} \mathrm{O}$ & $10024-97-2$ & SUMMA ${ }^{\text {TM }}$ & 3 & 701 & 2.5 & 0.4 \\
\hline Water Vapor, $\mathrm{H}_{2} \mathrm{O}$ & $7732-18-5$ & Sorbent Trap & 6 & $\begin{array}{l}15,800 \\
(11.4 \mathrm{mg} / \mathrm{L})\end{array}$ & $\begin{array}{l}200 \\
(0.16 \mathrm{mg} / \mathrm{L})\end{array}$ & 1.4 \\
\hline
\end{tabular}

$1 \mathrm{CAS}=$ Chemical Abstracts Service

$2 \mathrm{RSD}=$ relative standard deviation. Burnum (1995) specifies the RSD should be less than $25 \%$. 
WHC-SD-WM-ER-451 REV. 1

Table 4-1

Tank U-107 Quantitatively Measured Organic Compounds in SUMMA ${ }^{\text {TM }}$ Samples Analyses by Pacific Northwest Laboratory

\begin{tabular}{|c|c|c|c|c|c|}
\hline$\underset{\#}{\text { Cmpd }}$ & Compound & $\begin{array}{c}\text { CAS }^{1} \\
\text { Number }\end{array}$ & $\begin{array}{l}\text { Average }^{2} \\
\text { (ppmv) }\end{array}$ & $\begin{array}{c}\text { Standard } \\
\text { Deviation } \\
\text { (ppmv) }\end{array}$ & $\begin{array}{c}\mathrm{RSD}^{4} \\
(\%)\end{array}$ \\
\hline 1 & Propanone (acetone) & $67-64-1$ & 0.28 & 0.02 & 9 \\
\hline 2 & Trichlorofluoromethane & $75-69-4$ & 0.39 & 0.03 & 7 \\
\hline 3 & Propanenitrile $^{5}$ & $107-12-0$ & 0.062 & - & - \\
\hline 4 & 1-Propanol & $71-23-8$ & 0.050 & 0.012 & 25 \\
\hline 5 & 2-Butanone ${ }^{6}$ & $78-93-3$ & 0.024 & $<0.0015$ & - \\
\hline 6 & Tetrahydrofuran & $109-99-9$ & 0.029 & 0.002 & 8 \\
\hline 7 & Benzene & $71-43-2$ & 0.032 & 0.002 & 6 \\
\hline 8 & Cyclohexane & $110-82-7$ & 0.084 & 0.005 & 6 \\
\hline 9 & Pyridine & $110-86-1$ & 0.038 & 0.032 & 83 \\
\hline 10 & Toluene & $108-88-3$ & 0.046 & 0.004 & 8 \\
\hline $\begin{array}{c}11 \& \\
12\end{array}$ & $\begin{array}{l}\mathrm{p}-X y l e n e \\
\text { and } \mathrm{m} \text {-Xyiene } \mathrm{e}^{5,7}\end{array}$ & $\begin{array}{l}106-42-3 \\
108-38-3\end{array}$ & 0.018 & $<0.005$ & -- \\
\hline 13 & Methane & $74-82-8$ & $<12$ & - & - \\
\hline \multicolumn{3}{|c|}{ Sum of positively identified compounds: } & 4.4 & $\mathrm{mg} / \mathrm{m}^{3}$ & \\
\hline
\end{tabular}

$1 \mathrm{CAS}=$ Chemical Abstract Service.

2 Average of 3 samples.

3 When the analyte was detected in only 2 samples, the entry is the relative difference (i.e., their difference divided by 2).

$4 \mathrm{RSD}=$ relative standard deviation. Burnum (1995) specifies the RSD should be less than $25 \%$.

5 Detected in only 1 sample.

6 Detected in only 2 samples.

$7 \mathrm{~m}$-xylene and p-xylene coelute and the reported value represents the sum of their concentrations. 
WHC-SD-WM-ER-451 REV. 1

Table 4-2

Tank U-107 Quantitatively Measured Organic Compounds in TST Samples Analyses by Oak Ridge National Laboratory ${ }^{1}$

\begin{tabular}{clcccc}
\hline $\begin{array}{c}\text { Cmpd } \\
\#\end{array}$ & Compound & $\begin{array}{c}\text { CAS }^{2} \\
\text { Number }\end{array}$ & $\begin{array}{c}\text { Average } \\
\text { (ppmv) }\end{array}$ & $\begin{array}{c}\text { Standard } \\
\text { Deviation } \\
\text { (ppmv) }\end{array}$ & $\begin{array}{c}\text { RSD }^{4} \\
(\%)\end{array}$ \\
\hline \hline 1 & Ethanenítrile (acetonitrile) & $75-05-8$ & 0.12 & 0.01 & 8 \\
2 & Benzene & $71-43-2$ & 0.0029 & 0.0047 & 16 \\
3 & Toluene & $108-88-3$ & 0.032 & 0.002 & 7 \\
4 & n-Dodecane & $112-40-3$ & 0.0041 & 0.0002 & 4 \\
5 & n-Tridecane & $629-50-5$ & 0.010 & 0.0002 & 2 \\
\hline \hline
\end{tabular}

1 Results in this table are quantitative (as defined in Section 4.1).

$2 \mathrm{CAS}=$ Chemical Abstract Service.

3 Average of 3, 1-L TST samples.

4 RSD = relative standard deviation. Burnum (1995) specifies the RSD should be less than $25 \%$. 
WHC-SD-WM-ER-451 REV. 1

Table 4-3

Tank U-107 Positively Identified Organic Compounds in TST Samples -Analyses by Oak Ridge National Laboratory ${ }^{1}$

\begin{tabular}{clcccc}
\hline $\begin{array}{c}\text { Cmpd } \\
\#\end{array}$ & Compound & $\begin{array}{c}\text { CAS }^{2} \\
\text { Number }\end{array}$ & $\begin{array}{c}\text { Average } \\
\text { (ppmv) }\end{array}$ & $\begin{array}{c}\text { Standard } \\
\text { Deviation } \\
\text { (ppmv) }\end{array}$ & $\begin{array}{c}\mathrm{RSD}^{4} \\
(\%)\end{array}$ \\
\hline \hline 1 & Propanone (acetone) & $67-64-1$ & 0.0080 & 0.0004 & 5 \\
2 & Dichloromethane (methylene chloride) & $75-09-2$ & 0.0032 & 0.0029 & 92 \\
3 & Propanenitrile & $107-12-0$ & 0.0036 & 0.0003 & 9 \\
4 & n-Hexane & $110-54-3$ & 0.0077 & 0.0023 & 30 \\
5 & n-Butanenitrile & $109-74-0$ & 0.0062 & 0.0009 & 14 \\
6 & n-Heptane & $142-82-5$ & 0.0030 & 0.0002 & 5 \\
7 & n-Pentanenitrile & $110-59-8$ & 0.00038 & 0.00005 & 12 \\
8 & 2-Hexanone & $591-78-6$ & 0.00062 & 0.00012 & 20 \\
9 & n-Octane & $111-65-9$ & 0.0024 & 0.0002 & 7 \\
10 & 2-Heptanone & $110-43-0$ & 0.00071 & 0.00009 & 13 \\
11 & n-Nonane & $111-84-2$ & 0.0022 & 0.0002 & 10 \\
12 & 2-Octanone & $111-13-7$ & 0.00046 & 0.00005 & 10 \\
13 & n-Decane & $124-18-5$ & 0.0030 & 0.0004 & 14 \\
14 & n-Undecane & $1120-21-4$ & 0.0025 & 0.0003 & 13 \\
\hline \hline
\end{tabular}

1 Results in this table are not quantitative (as defined in Section 4.1) because measured values in at least 1 of the samples are outside instrument calibration limits.

2 CAS $=$ Chemical Abstract Service.

3 Average of 3, 1-L TST samples.

4 RSD = relative standard deviation. Burnum (1995) specifies the RSD should be less than $25 \%$. 
WHC-SD-WM-ER-451 REV. 1

Table 4-4

Tank U-107 Positively Identified Compounds in TST Samples

for which Practical Holding Times were Exceeded -Analyses by Oak Ridge National Laboratory ${ }^{1}$

\begin{tabular}{cccccc}
\hline \hline $\begin{array}{c}\text { Cmpd } \\
\#\end{array}$ & Compound & $\begin{array}{c}\mathrm{CAS}^{2} \\
\text { Number }\end{array}$ & $\begin{array}{c}\text { Average } \\
\text { (ppmv) }\end{array}$ & $\begin{array}{c}\text { Standard } \\
\text { Deviation } \\
\text { (ppmv) }\end{array}$ & $\begin{array}{c}\mathrm{RSD}^{4} \\
(\%)\end{array}$ \\
\hline \hline 1 & 1 -Butanol & $71-36-3$ & 0.070 & 0.005 & 7 \\
\hline \hline
\end{tabular}

1 Practical holding times are defined and discussed in Section 4.1. The result given for 1-butanol is quantitative (as defined in Section 4.0).

$2 \mathrm{CAS}=$ Chemical Abstract Service.

3 Average of 3, 1-L TST samples.

4 RSD = relative standard deviation. Burnum (1995) specifies the RSD should be less than $25 \%$. 
Table 4-5

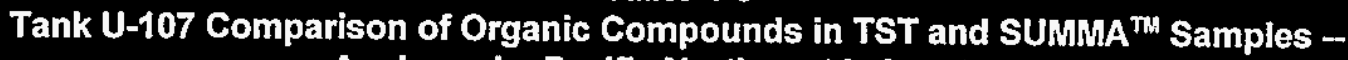
Analyses by Pacific Northwest Laboratory and Oak Ridge National Laboratory

\begin{tabular}{lcccc}
\hline Compound & $\begin{array}{c}\text { CAS }^{1} \\
\text { Number }\end{array}$ & $\begin{array}{c}\text { TST } \\
\text { Average }^{2} \\
\text { (ppmv) }\end{array}$ & $\begin{array}{c}\text { SUMMA } \\
\text { Average }^{3} \\
\text { (ppmv) }\end{array}$ & $\begin{array}{c}\text { PRD }^{4} \\
(\%)\end{array}$ \\
\hline \hline 1,1-Dichloroethene (vinylidene chloride) & $75-35-4$ & $<0.0023$ & $<0.005$ & - \\
Dichloromethane (methylene chloride) & $75-09-2$ & 0.0032 & $<0.005$ & - \\
Propanone (acetone) & $67-64-1$ & 0.0080 & 0.28 & 189 \\
Ethanenitrile (acetonitrile) & $75-05-8$ & 0.12 & $<0.005$ & $>184$ \\
Propanenitrile & $107-12-0$ & 0.0036 & $0.062^{5}$ & 178 \\
n-Butanenitrile & $109-74-0$ & 0.0062 & $<0.005$ & $>21$ \\
Benzene & $71-43-2$ & 0.0029 & 0.032 & 167 \\
Toluene & $108-88-3$ & 0.032 & 0.046 & 36 \\
n-Hexane & $110-54-3$ & 0.0077 & $<0.005$ & $>42$ \\
n-Heptane & $142-82-5$ & 0.0030 & $<0.005$ & - \\
n-Decane & $124-18-5$ & 0.0030 & $<0.005$ & - \\
\hline \hline
\end{tabular}

$1 \mathrm{CAS}=$ Chemical Abstract Service.

2 Average of 3, 1-L TST sample analyses.

3 Average of 3 sample analyses.

$4 \mathrm{PRD}=$ percent relative difference. Keller (1994) requires the PRD to be less than $20 \%$.

5 Detected in only 1 sample 
Table 4-6

Tank U-107 Tentatively Identified Organic Compounds in SUMMA ${ }^{\text {TM }}$ Samples -Analyses by Pacific Northwest Laboratory

\begin{tabular}{|c|c|c|c|c|}
\hline $\begin{array}{c}\text { Cmpd } \\
\#\end{array}$ & Compound & $\begin{array}{c}\mathrm{CAS}^{1} \\
\text { Number }\end{array}$ & $\begin{array}{c}\text { Average }^{2} \\
\left(\mathrm{mg} / \mathrm{m}^{3}\right)\end{array}$ & $\begin{array}{c}\text { Standard } \\
\text { Deviation } \\
\left(\mathrm{mg} / \mathrm{m}^{3}\right)\end{array}$ \\
\hline 1 & Propene ${ }^{4}$ & $115-07-1$ & 0.091 & $<0.02$ \\
\hline 2 & Propane & $74-98-6$ & 0.34 & 0.05 \\
\hline 3 & Dimethyl ether & $115-10-6$ & 0.072 & 0.005 \\
\hline 4 & Cyclopropane $^{3}$ & $75-19-4$ & 0.18 & $<0.005$ \\
\hline 5 & Isobutane & $75-28-5$ & 0.20 & 0.01 \\
\hline 6 & Methanol (methyl alcohol) & $67-56-1$ & 3.13 & 0.41 \\
\hline 7 & 1-Butene ${ }^{3}$ & $106-98-9$ & 0.13 & $<0.025$ \\
\hline 8 & n-Butane & $106-97-8$ & 0.24 & 0.02 \\
\hline 9 & Propane, 2,2-dimethyl- & $463-82-1$ & 0.12 & 0.02 \\
\hline 10 & 1-Propene, 2-methyl- & $115-11-7$ & 0.072 & 0.007 \\
\hline 11 & Methane, dichlorofluoro- ${ }^{5}$ & $75-43-4$ & 0.053 & - \\
\hline 12 & Ethanol & $64-17-5$ & 6.33 & 0.75 \\
\hline 13 & Isopropyl Alcohol ${ }^{3}$ & $67-63-0$ & 0.29 & $<0.015$ \\
\hline 14 & $\mathrm{n}$-Pentane & $109-66-0$ & 0.18 & 0.003 \\
\hline 15 & Butane, 2,2-dimethy:- ${ }^{3}$ & $75-83-2$ & 0.22 & $<0.01$ \\
\hline 16 & Pentane, 2-methyl- & $107-83-5$ & 0.23 & 0.02 \\
\hline 17 & Pentane, 3-methyl-4 & $96-14-0$ & 0.089 & -- \\
\hline 18 & 1-Butanol & $71-36-3$ & 0.91 & 0.02 \\
\hline 19 & Pyrazine 4 & $290-37-9$ & 0.054 & - \\
\hline \multicolumn{3}{|c|}{ Sum of tentatively identified compounds: } & 12.73 & \\
\hline
\end{tabular}

$1 \mathrm{CAS}=$ Chemical Abstract Service .

2 Based on analyses of 3 samples, values presented are estimated.

3 When the analyte was detected in only 2 samples, the entry is the relative difference (i.e., their difference divided by 2).

4 Detected in only 2 samples.

5 Detected in only 1 sample. 
Table 4-7

Tank U-107 Tentatively Identified Organic Compounds in TST Samples In Order of Chromatographic Elution -Analyses by Oak Ridge National Laboratory

\begin{tabular}{|c|c|c|c|c|}
\hline Cmpd & Compounds & $\begin{array}{l}\text { CAS }^{1} \\
\text { Number }\end{array}$ & $\begin{array}{l}\text { Average }^{2} \\
\left(\mathrm{mg} / \mathrm{m}^{3}\right)\end{array}$ & $\begin{array}{c}\text { Standard } \\
\text { Deviation } \\
\left(\mathrm{mg} / \mathrm{m}^{3}\right) \\
\end{array}$ \\
\hline 1 & Methanol (methyl alcohol) & $67-56-1$ & 0.83 & 0.06 \\
\hline 2 & Ethanol & $64-17-5$ & 2.83 & 0.84 \\
\hline 3 & Trichlorofluoromethane & $75-69-4$ & 0.70 & 0.25 \\
\hline 4 & 2-Propanol (isopropyl alcohol) & $67-63-0$ & 0.17 & 0.03 \\
\hline 5 & Butane, 2,2-dimethyl- & $75-83-2$ & 0.039 & 0.003 \\
\hline 6 & Butane, 2,3-dimethyl- & $79-29-8$ & 0.011 & 0.018 \\
\hline 7 & Pentane, 2-methyl- & $107-83-5$ & 0.088 & 0.011 \\
\hline 8 & 1-Propanol & $71-23-8$ & 0.044 & 0.006 \\
\hline 9 & Pentane, 3-methyl- & $96-14-0$ & 0.039 & 0.006 \\
\hline 10 & Furan, tetrahydro- & $109-99-9$ & 0.057 & 0.045 \\
\hline 11 & Ethanal (acetaldehyde) & $75-07-0$ & 0.0081 & 0.0141 \\
\hline 12 & Isobutane & $75-28-5$ & 0.037 & 0.033 \\
\hline 13 & Pyrazine & $290-37-9$ & 0.13 & 0.01 \\
\hline 14 & Propane, 2-methyl-2-nitro- & $594-70-7$ & 0.037 & 0.006 \\
\hline 15 & N-Nitrosodimethylamine & $62-75-9$ & 0.044 & 0.013 \\
\hline 16 & 2-Propanol, 1-(1-methylethoxy)- & $3944-36-3$ & 0.011 & 0.019 \\
\hline 17 & Pentanal, 3-methyl- & $15877-57-3$ & 0.039 & 0.024 \\
\hline 18 & Tetrachloroethylene & $127-18-4$ & 0.025 & 0.022 \\
\hline 19 & Pyrazine, methyl- & $109-08-0$ & 0.0044 & 0.0076 \\
\hline 20 & Ethylbenzene & $100-41-4$ & 0.0075 & 0.0131 \\
\hline 21 & p-Xylene & $106-42-3$ & 0.081 & 0.007 \\
\hline 22 & p-Xylene & $106-42-3$ & 0.0092 & 0.0160 \\
\hline 23 & Octane, 2,5,6-trimethyl- & $62016-14-2$ & 0.031 & 0.000 \\
\hline 24 & $\begin{array}{l}\text { Phenol and } \\
\text { cyciotetrasiloxane, octamethyl- }\end{array}$ & & 0.004 & 0.007 \\
\hline 25 & Octane, 3-ethyl-2, 7-dimethyl- & $62183-55-5$ & 0.0048 & 0.0083 \\
\hline
\end{tabular}


WHC-SD-WM-ER-451 REV. 1

\begin{tabular}{|c|c|c|c|c|}
\hline $\begin{array}{c}\text { Cmpd } \\
\#\end{array}$ & Compounds & $\begin{array}{l}\text { CAS' } \\
\text { Number }\end{array}$ & $\begin{array}{c}\text { Average }^{2} \\
\left(\mathrm{mg} / \mathrm{m}^{3}\right)\end{array}$ & $\begin{array}{c}\text { Standard } \\
\text { Deviation } \\
\left(\mathrm{mg} / \mathrm{m}^{3}\right)\end{array}$ \\
\hline 26 & Undecane, 2,2-dimethyl- & $17312-64-0$ & 0.0054 & 0.0093 \\
\hline 27 & 1-Hexanol, 2-ethyl- & $104-76-7$ & 0.006 & 0.010 \\
\hline 28 & Nonane, 5-butyl- & $17312-63-9$ & 0.007 & 0.012 \\
\hline 29 & Benzyl Alcohol & $100-51-6$ & 0.0042 & 0.0073 \\
\hline 30 & Hexane, 2,2,3-trimethyl- & $16747-25-4$ & 0.0063 & 0.0110 \\
\hline 31 & Hexane, 2,2,5-trimethyl- & $3522-94-9$ & 0.0048 & 0.0083 \\
\hline 32 & Decane, 3-methyl- & $13151-34-3$ & 0.0063 & 0.0110 \\
\hline 33 & Heptane, 2,2,4-trimethyl- & $14720-74-2$ & 0.0027 & 0.0048 \\
\hline 34 & Naphthalene and others & & 0.0032 & 0.0056 \\
\hline 35 & Tetradecane & $629-59-4$ & 0.0056 & 0.0096 \\
\hline 36 & Benzenesulfonamide, $\mathrm{N}$-butyl & $3622-84-2$ & 0.099 & 0.019 \\
\hline 37 & Isopropy! Palmitate & $142-91-6$ & 0.0045 & 0.0078 \\
\hline \multicolumn{2}{|c|}{ Sum of tentatively identified compounds: } & & 5.43 & \\
\hline
\end{tabular}

$1 \mathrm{CAS}=$ Chemical Abstract Service.

2 Based on analyses of 3 samples, values presented are estimated. 
Table 4-8

Tank U-107 Tentatively Identified Organic Compounds in TST Samples

Sorted Alphanumerically --

Analyses by Oak Ridge National Laboratory

\begin{tabular}{|c|c|c|c|c|}
\hline Cmpd & Compound & $\begin{array}{l}\text { CAS }^{1} \\
\text { Number }\end{array}$ & $\begin{array}{c}\text { Average }^{2} \\
\left(\mathrm{mg} / \mathrm{m}^{3}\right)\end{array}$ & $\begin{array}{c}\text { Standard } \\
\text { Deviation } \\
\left(\mathrm{mg} / \mathrm{m}^{3}\right) \\
\end{array}$ \\
\hline 8 & 1-Propanol & $71-23-8$ & 0.044 & 0.006 \\
\hline 27 & 1-Hexanol, 2-ethyl- & $104-76-7$ & 0.006 & 0.010 \\
\hline 16 & 2-Propanol, 1-(1-methylethoxy)- & $3944-36-3$ & 0.011 & 0.019 \\
\hline 4 & 2-Propanol (isopropyl alcohol) & $67-63-0$ & 0.17 & 0.03 \\
\hline 36 & Benzenesulfonamide, N-butyl & $3622-84-2$ & 0.099 & 0.019 \\
\hline 29 & Benzyl Alcohol & $100-51-6$ & 0.0042 & 0.0073 \\
\hline 5 & Butane, 2,2-dimethyl- & $75-83-2$ & 0.039 & 0.003 \\
\hline 6 & Butane, 2,3-dimethyl- & $79-29-8$ & 0.011 & 0.018 \\
\hline 32 & Decane, 3-methyl- & $13151-34-3$ & 0.0063 & 0.0110 \\
\hline 11 & Ethanal (acetaldehyde) & $75-07-0$ & 0.0081 & 0.0141 \\
\hline 2 & Ethanol & $64-17-5$ & 2.83 & 0.84 \\
\hline 20 & Ethylbenzene & $100-41-4$ & 0.0075 & 0.0131 \\
\hline 10 & Furan, tetrahydro- & $109-99-9$ & 0.057 & 0.045 \\
\hline 33 & Heptane, 2,2,4-trimethyl- & $14720-74-2$ & 0.0027 & 0.0048 \\
\hline 30 & Hexane, 2,2,3-trimethyl- & $16747-25-4$ & 0.0063 & 0.0110 \\
\hline 31 & Hexane, 2,2,5-trimethyl- & $3522-94-9$ & 0.0048 & 0.0083 \\
\hline 12 & Isobutane & $75-28-5$ & 0.037 & 0.033 \\
\hline 37 & Isopropyl Palmitate & $142-91-6$ & 0.0045 & 0.0078 \\
\hline 1 & Methanol (methyl alcohol) & $67-56-1$ & 0.83 & 0.06 \\
\hline 15 & N-Nitrosodimethylamine & $62-75-9$ & 0.044 & 0.013 \\
\hline 34 & Naphthalene and others & & 0.0032 & 0.0056 \\
\hline 28 & Nonane, 5-butyl- & $17312-63-9$ & 0.007 & 0.012 \\
\hline 23 & Octane, 2,5,6-trimethyl- & $62016-14-2$ & 0.031 & 0.000 \\
\hline 25 & Octane, 3-ethyl-2, 7-dimethyl- & $62183-55-5$ & 0.0048 & 0.0083 \\
\hline 21 & p-Xylene & $106-42-3$ & 0.081 & 0.007 \\
\hline 22 & p-Xylene & $106-42-3$ & 0.0092 & 0.0160 \\
\hline
\end{tabular}


WHC-SD-WM-ER-451 REV. 1

\begin{tabular}{|c|c|c|c|c|}
\hline $\begin{array}{c}\text { Cmpd } \\
\#\end{array}$ & Compound & $\begin{array}{l}\text { CAS }^{1} \\
\text { Number }\end{array}$ & $\begin{array}{l}\text { Average }^{2} \\
\left(\mathrm{mg} / \mathrm{m}^{3}\right)\end{array}$ & $\begin{array}{c}\text { Standard } \\
\text { Deviation } \\
\left(\mathrm{mg} / \mathrm{m}^{3}\right) \\
\end{array}$ \\
\hline 17 & Pentanal, 3-methyl- & $15877-57-3$ & 0.039 & 0.024 \\
\hline 7 & Pentane, 2-methyl- & $107-83-5$ & 0.088 & 0.011 \\
\hline 9 & Pentane, 3-methyl- & $96-14-0$ & 0.039 & 0.006 \\
\hline 24 & $\begin{array}{l}\text { Phenol and } \\
\text { cyclotetrasiloxane, octamethyl- }\end{array}$ & & 0.004 & 0.007 \\
\hline 14 & Propane, 2-methyl-2-nitro- & $594-70-7$ & 0.037 & 0.006 \\
\hline 13 & Pyrazine & $290-37-9$ & 0.13 & 0.01 \\
\hline 19 & Pyrazine, methyl- & $109-08-0$ & 0.0044 & 0.0076 \\
\hline 18 & Tetrachloroethylene & $127-18-4$ & 0.025 & 0.022 \\
\hline 35 & Tetradecane & $629-59-4$ & 0.0056 & 0.0096 \\
\hline 3 & Trichlorofluoromethane & $75-69-4$ & 0.70 & 0.25 \\
\hline 26 & Undecane, 2,2-dimethyl- & $17312-64-0$ & 0.0054 & 0.0093 \\
\hline \multicolumn{2}{|c|}{ Sum of tentatively identified compounds: } & & 5.43 & \\
\hline
\end{tabular}

$1 \mathrm{CAS}=$ Chemical Abstract Service.

2 Average of 3,1-L TST samples by ORNL, values presented are estimated. 
Table 4-9

Tank U-107 Tentatively Identified Organic Compounds in TST Samples Sorted by Estimated Concentration Analyses by Oak Ridge National Laboratory

\begin{tabular}{|c|c|c|c|c|}
\hline$\underset{\#}{\text { Cmpd }}$ & Compounds & $\begin{array}{l}\text { CAS }^{1} \\
\text { Number }\end{array}$ & $\begin{array}{l}\text { Average }^{2} \\
\left(\mathrm{mg} / \mathrm{m}^{3}\right)\end{array}$ & $\begin{array}{c}\text { Standard } \\
\text { Deviation } \\
\left(\mathrm{mg} / \mathrm{m}^{3}\right)\end{array}$ \\
\hline 2 & Ethanol & $64-17-5$ & 2.83 & 0.84 \\
\hline 1 & Methanol (methyl alcohol) & $67-56-1$ & 0.83 & 0.06 \\
\hline 3 & Trichlorofluoromethane & $75-69-4$ & 0.70 & 0.25 \\
\hline 4 & 2-Propanol (isopropyl alcohol) & $67-63-0$ & 0.17 & 0.03 \\
\hline 13 & Pyrazine & $290-37-9$ & 0.13 & 0.01 \\
\hline 36 & Benzenesulfonamide, $N$-butyl & $3622-84-2$ & 0.099 & 0.019 \\
\hline 7 & Pentane, 2-methyl- & $107-83-5$ & 0.088 & 0.011 \\
\hline 21 & p-Xylene & $106-42-3$ & 0.081 & 0.007 \\
\hline 10 & Furan, tetrahydro- & $109-99-9$ & 0.057 & 0.045 \\
\hline 8 & 1-Propanol & $71-23-8$ & 0.044 & 0.006 \\
\hline 15 & N-Nitrosodimethylamine & $62-75-9$ & 0.044 & 0.013 \\
\hline 9 & Pentane, 3-methyl- & $96-14-0$ & 0.039 & 0.006 \\
\hline 5 & Butane, 2,2-dimethyl- & $75-83-2$ & 0.039 & 0.003 \\
\hline 17 & Pentanal, 3-methyl- & $15877-57-3$ & 0.039 & 0.024 \\
\hline 12 & Isobutane & $75-28-5$ & 0.037 & 0.033 \\
\hline 14 & Propane, 2-methyl-2-nitro- & $594-70-7$ & 0.037 & 0.006 \\
\hline 23 & Octane, 2,5,6-trimethyl- & $62016-14-2$ & 0.031 & 0.000 \\
\hline 18 & Tetrachloroethylene & $127-18-4$ & 0.025 & 0.022 \\
\hline 16 & 2-Propanol, 1-(1-methylethoxy)-. & $3944-36-3$ & 0.011 & 0.019 \\
\hline 6 & Butane, 2,3-dimethyl- & $79-29-8$ & 0.011 & 0.018 \\
\hline 22 & p-Xylene & $106-42-3$ & 0.0092 & 0.0160 \\
\hline 11 & Ethanal (acetaldehyde) & $75-07-0$ & 0.0081 & 0.0141 \\
\hline 20 & Ethylbenzene & $100-41-4$ & 0.0075 & 0.0131 \\
\hline 24 & $\begin{array}{l}\text { Phenol and } \\
\text { cyclotetrasiloxane, octamethyl- }\end{array}$ & & 0.004 & 0.007 \\
\hline 28 & Nonane, 5-butyl- & $17312-63-9$ & 0.007 & 0.012 \\
\hline
\end{tabular}


WHC-SD-WM-ER-451 REV. 1

\begin{tabular}{llrrr}
\hline \hline $\begin{array}{c}\text { Cmpd } \\
\#\end{array}$ & Compounds & $\begin{array}{c}\text { CAS }^{1} \cdot \\
\text { Number }\end{array}$ & $\begin{array}{c}\text { Average } \\
\left(\mathrm{mg} / \mathrm{m}^{3}\right)\end{array}$ & $\begin{array}{c}\text { Standard } \\
\text { Deviation } \\
\left(\mathrm{mg}^{3}\right)\end{array}$ \\
\hline \hline 32 & Decane, 3-methyl- & $13151-34-3$ & 0.0063 & 0.0110 \\
30 & Hexane, 2,2,3-trimethyl- & $16747-25-4$ & 0.0063 & 0.0110 \\
27 & 1-Hexanol, 2-ethyl- & $104-76-7$ & 0.006 & 0.010 \\
35 & Tetradecane & $629-59-4$ & 0.0056 & 0.0096 \\
26 & Undecane, 2,2-dimethyl- & $17312-64-0$ & 0.0054 & 0.0093 \\
31 & Hexane, 2,2,5-trimethyl- & $3522-94-9$ & 0.0048 & 0.0083 \\
25 & Octane, 3-ethyl-2, 7-dimethyl- & $62183-55-5$ & 0.0048 & 0.0083 \\
37 & Isopropyl Palmitate & $142-91-6$ & 0.0045 & 0.0078 \\
19 & Pyrazine, methyl- & $109-08-0$ & 0.0044 & 0.0076 \\
29 & Benzyl Alcohol & $100-51-6$ & 0.0042 & 0.0073 \\
34 & Naphthalene and others & & 0.0032 & 0.0056 \\
33 & Heptane, 2,2,4-trimethyl- & $14720-74-2$ & 0.0027 & 0.0048 \\
\hline \hline Sum of tentatively identified compounds: & & 5.43 & \\
\hline \hline
\end{tabular}

$1 \mathrm{CAS}=$ Chemical Abstract Service.

2 Average of 3, 1-L TST samples by ORNL, values presented are estimated. 